\title{
Scientific Method in Physical Education Learning: A Cross-Sectional Study
}

\section{Nune Wire Panji Sakti, Rusdiana Yusuf, Adi Suriatno, *Johan Irmansyah}

Department of Sport and Health Education, Faculty of Sports Science and Public Health, Universitas Pendidikan Mandalika. Jl. Pemuda No. 59A, Mataram, 83125, Indonesia

*Corresponding Author e-mail: johanirmansyah@undikma.ac.id

Received: September 2021; Revised: October 2021; Published: November 2021

\begin{abstract}
The physical education learning process through the scientific method emphasizes finding information about the basic techniques/skills taught and game rules to find solutions to every problem encountered. This study aims to determine the results of the implementation of the scientific method in learning physical education. The study design was a cross-sectional study. There were 386 students and three physical education teachers participants. The data collection procedure in this study used an assessment questionnaire for students and an interview protocol for physical education teachers. Two research instruments were used: student questionnaire sheets and teacher interview protocols. Student questionnaire data were analyzed using quantitative descriptive and physical education teacher interview data were analyzed using qualitative descriptive. The results of the assessment of the response of class students indicate that the implementation of the scientific method in physical education learning has been going very well. This is evidenced by the percentage value of the assessment of more than $75 \%$, both in the initial, core, and final activity variables. This research has an impact on increasing the knowledge and competence of teachers related to scientific methods and improving the quality of physical education learning.
\end{abstract}

Keywords: cross-sectional study; learning model; physical education; scientific method

How to Cite: Sakti, N. W. P., Yusuf, R., Suriatno, A., \& Irmansyah, J. (2021). The Scientific Method in Physical Education Learning: A Cross-Sectional Study. Jurnal Penelitian Dan Pengkajian Ilmu Pendidikan: E-Saintika, 5(3), 212-226. https://doi.org/10.36312/esaintika.v5i3.571

https:// doi.org/10.36312/esaintika.v5i3.571

Copyright@ 2021, Sakti et al This is an open-access article under the CC-BY-SA License.

\section{INTRODUCTION}

Physical education is an educational process that utilizes planned physical activities systematically and aims to develop and improve individuals organically, neuromuscularly, perceptually, cognitively, and emotionally, within the framework of the national education system (Rachman, 2011). Relevant to the definition, Harsuki (2013) explains physical education as an educational process through physical activity that directs children to learn, so that changes in behaviour occur, not only regarding physical aspects, but also intellectual, emotional, social, and moral. Furthermore, Bayu (2018) argues that physical education is a process of learning to move, and learning through motion.

In the context of physical education, educational values are instilled through the learning process of physical activity or sports that emphasizes learning about movement and sports skills, physical fitness, and a healthy lifestyle (Jatmika et al., 
2017). This has also been formulated in the 2013 curriculum which emphasizes the achievement of attitude, knowledge, and skill competencies through physical education learning (Kemendikbud Republik Indonesia, 2018). The implementation of physical education learning requires a learning plan to be used as a learning operational guide. Learning planning is the process of preparing subject matter, using learning media methods in an allocation of time that will be carried out to achieve the goals that have been set (Pambudi et al., 2019). The purpose of learning planning is as a guide or guide for teachers, as well as directing and guiding the activities of teachers and students in the learning process (Rachman, 2011). The learning method is the most important part in carrying out the learning process, so it must be carried out in an interesting way that is able to arouse the interest of students to carry out learning (Beni et al., 2017).

Learning in the 2013 curriculum can be implemented using scientific-based methods, namely learning that adopts scientific steps in building knowledge through scientific methods. This method emphasizes the process of seeking knowledge related to learning experiences through observing, questioning, experimenting, associating, and communicating (Gerde et al., 2013). In the process of learning physical education through scientific methods, students are required to seek as much information as possible about the basic techniques/skills taught, game rules, to find solutions to every problem encountered in the game (Rahmat et al., 2019). The end result of this learning process is an increase and balance between the ability to become individuals who have character (soft skills) and humans who have the skills and knowledge to live properly (hard skills) (Sinulingga \& Nugraha, 2013).

The scientific method is the right method used in the learning process, because it can help students solve various kinds of problems with the planning and analysis process. The scientific method is a learning method that guides students to act like science experts, so that they can encourage students to develop skills in active learning, critical thinking, and problem solving (Vieira \& Tenreiro-Vieira, 2016). The scientific method also focuses on student-centered learning (Memmert et al., 2015), provide opportunities for students to communicate (Rasberry et al., 2011), deeper understanding of learning materials (Winnick \& Porretta, 2017), and emphasis on character building of students (Irmansyah, Lumintuarso, et al., 2020). The purpose of learning with the scientific method is based on the advantages of the method, including; (1) improve intellectual abilities, especially higher-order thinking skills, (2) shape the ability of students to solve a problem systematically, (3) create learning conditions where students feel that learning is a necessity, (4) obtain learning outcomes a high level, (5) train students in communicating ideas, especially in writing scientific articles, and (6) to develop the character of students (Machin, 2014).

The results of research from Mustafa and Winarno (2020) explain the quality of the implementation of physical education learning with the scientific method, as follows; (1) The quality of learning planning has a very good category, but revisions are needed in formulating learning objectives; (2) The quality of the learning process has a good category, but revisions are needed in time management and the learning process must be interrelated between the material and the objectives achieved; and (3) the quality of the assessment of learning outcomes has a good category, but revisions are needed in the assessment carried out, both aspects of attitude, knowledge, and skills. These results indicate that the application of the scientific method has an impact on improving the skills, knowledge, and character of students. However, the results 
of this study cannot be generalized and are used as the only reference in determining the effectiveness of the scientific method in learning physical education.

The results of the needs analysis in the field conducted through interviews with physical education teachers at SMA Negeri 3 Mataram, explained that the school has been using the 2013 curriculum since 2017 and has been applied to class X, XI, and XII students. The implementation of the 2013 curriculum has been supported by the existence of adequate facilities and infrastructure and supports physical education learning at SMA Negeri 3 Mataram, such as; the availability of basketball, volleyball, futsal and badminton courts, table tennis facilities, and gymnastics and athletics learning facilities. In addition, classrooms that support the learning process are also good, such as; the availability of LCDs and projectors in every classroom, fans, blackboards, desks, and study chairs according to the number of students. Existing human resources also meet the criteria, namely there are 4 physical education teachers at SMA Negeri 3 Mataram who have met the minimum academic qualifications of undergraduate education. Physical education teachers at SMA Negeri 3 Mataram have also attended 2013 curriculum implementation training, so it is hoped that after attending the training teachers are able to carry out tasks in accordance with the demands of graduate competencies, content, learning processes, and assessments in the 2013 curriculum.

In general, physical education teachers at SMA Negeri 3 Mataram have an understanding of the 2013 curriculum, but in terms of implementation, teachers still find it difficult to apply the learning model, even though the teacher already knows the procedures that must be carried out in the scientific method. In addition, the complexity of the preparation of learning implementation plans that must pay attention to the interrelationships and integration between core competencies, basic competencies, indicators of competency achievement, learning materials, learning activities, assessments, and learning resources in one whole learning experience (Irmansyah, Sakti, et al., 2020). The preparation of learning implementation plans must also be student-centered, which is designed to encourage motivation, interest, creativity, initiative, inspiration, independence, and enthusiasm for student learning. The learning implementation plan must also integrate PPK (strengthening character education), GLS (school literacy movement), 21st century skills with 4C (communication, collaboration, critical thinking and problem solving, and creativity and innovation) (Kemendikbud Republik Indonesia, 2019), which is another problem that must be faced and solved by the teacher in the learning process. Furthermore, the results of observations during the learning process, researchers found the fact that the teacher was still the center of learning or only from one direction (teaching-center) (Dole et al., 2015), so it can be concluded that there is still a combination of learning methods with the old curriculum and the new curriculum.

The results of implementing the physical education curriculum have also been discussed in several previous studies in various countries. Physical education curricula in many countries explicitly task teachers with the responsibility to support the health of their pupils (Gray et al., 2018). Research from Ennis (2011) explain the priorities of the physical education curriculum are cognitive development and understanding, connecting knowledge with meaningful physical activity, and student beliefs in physical education. Wainwright et al. (2016) also explained that the playbased curriculum in physical education learning can support the development of physical literacy (motivation, self-confidence, physical competence, knowledge and 
understanding). Specifically, the implementation of the physical education curriculum using various learning methods or approaches aims to develop the potential of students, which includes psychomotor, cognitive, affective, and social aspects.

This research has the potential to contribute to improving the quality of physical education learning in Indonesia, especially in high school education units. The use of scientific methods is still not very popular or rarely used in physical education learning (Mustafa \& Winarno, 2020), so this research is an effort to carry out a fundamental transformation in physical education learning. This research also explicitly explains that the basic principles of scientific methods are commonly used to support the development of children's language, literacy, and mathematics (Gerde et al., 2013), can also be used in physical education learning to support cognitive development, increase motivation, and acquisition of movement skills. Contextualization and implementation of the basic principles of the scientific method which is the uniqueness and conceptual idea in this research, and which distinguishes it from previous research.

Based on the results of previous studies, interviews with physical education teachers, and observations of the learning process, the researchers assumed that the implementation of the 2013 curriculum through scientific learning methods, was still not implemented optimally by physical education teachers at SMA Negeri 3 Mataram. Thus, a study or research is needed that can provide a description of the results of implementing the 2013 curriculum in the physical education learning process. This can also be used as a new breakthrough in physical education learning to adapt various models, methods, approaches, and learning strategies to improve the quality of physical education learning at all levels of education (UNESCO, 2015). Therefore, the purpose of this study was to determine the results of the implementation of the scientific method in learning physical education in class XI students of SMA Negeri 3 Mataram.

\section{METHOD}

\section{Research Design}

The design in this study used a cross-sectional study which is the most common design in sports-related research. Cross-sectional designs are also often referred to as survey designs, with one of the objectives of investigating gender differences in sports participation (Jones, 2015). This cross-sectional design takes samples from the entire population, and data collection is only done once from participants through questionnaires and interviews. Questionnaire data is used to describe and interpret objects statistically according to conditions in the field, or in this study it aims to obtain responses from students about the implementation of scientific methods in physical education learning. In addition to cross-sectional studies, researchers also use a qualitative descriptive approach (Creswell \& Poth, 2018) to interpret the results of physical education teacher interviews about the implementation of scientific methods in physical education learning. The results of this teacher's interview are then used as additional data to support the main data from the cross-sectional study.

\section{Participants}

The participants in this study represented students in class XI of SMAN 3 Mataram, totalling 386 children, and 3 physical education teachers who taught in class XI. Students who became participants were excluded from the analysis if they were not 
willing to fill out the procedure for filling out the questionnaire for the assessment of the implementation of scientific methods in physical education learning which was distributed via Google Form. The representative students in the analysis were 116, divided based on gender. In this group, 52 people were male $(44.8 \%)$ and 64 people were female $(55.2 \%)$. All students were aged between 15 - 18 years, with a mean age of 16.2 years $(S D=0.860)$. The specific criteria for this research were that the students must be in class XI SMA and be between 15-18 years old at the time of data collection.

\section{Data Collection}

The data collection procedure in this study used an assessment questionnaire (O'Donoghue, 2012) for students and interview protocol (J. Barker et al., 2011) for physical education teachers. The following were the procedures carried out in the process of collecting research data, as follows: (1) Request a research permit from LPPM UNDIKMA; (2) Requesting a recommendation from the head of SMAN 3 Mataram to carry out the research process; (3) Searching for physical education teacher data for class XI SMA Negeri 3 Mataram (4) Searching for student data for class XI SMA Negeri 3 Mataram; (5) Analyzing the lesson plans used during learning; (6) Observing the physical education learning process; (7) Distribute questionnaires to students via Google Form; (8) Conducting interviews with physical education teachers according to the interview protocol that researchers have formulated; (9) Collecting the results of filling out student questionnaires and the results of teacher interviews; (10) Analyzing research data.

\section{Research Instrument}

In this study, 2 research instruments were used, namely student questionnaire sheets and teacher interview protocols. The questionnaire sheet for assessing the results of the implementation of scientific methods in physical education learning was adapted from Permatasari (2017) who have previously conducted research related to the implementation of the scientific method. The results of the instrument validity test showed that there were 4 statements that fell out of the 37 statements that were formulated, resulting in 33 statements that were declared valid or had $\mathrm{r}$ count $>$ from $\mathrm{r}$ table. Furthermore, the instrument reliability test results show that the Cronbach Alpha value was 0.944 , so the instrument was declared reliable.

For the teacher interview protocol, 9 questions relevant to the research objectives had been formulated. The interview protocol was first checked by 2 physical education and sports experts, with Doctoral education qualifications. These two experts checked the suitability of the content and construct of the interview instrument/protocol with the objectives to be achieved in the research. Examination of the content and construct of this instrument was carried out by providing suggestions, feedback, and comments, without performing statistical analysis. It was done because the researcher formulated the instrument or interview protocol in qualitative research (Creswell \& Poth, 2018).

\section{Data Analysis}

Student questionnaire data were analyzed using quantitative descriptive, which was carried out by calculating the percentage of successful implementation of scientific methods in physical education learning. In conducting quantitative data analysis, the calculation results could be processed by adding up, compared with the expected amount, and obtaining a percentage. The percentage formula (\%) was calculated by comparing the number of assessment scores with the maximum number of scores 
generated, then the results were multiplied by one hundred (100) (O'Donoghue, 2012). The questionnaire instrument used a Likert scale technique (Andayani et al., 2016) with four criteria: (Score 1: Never, Score 2= Rarely, Score 3= Often, Score 4= Always). Furthermore, the interview data of physical education teachers were analyzed using qualitative descriptive, which aimed to describe the results of the teacher's perspective regarding the implementation of scientific methods in physical education.

\section{RESULTS AND DISCUSSION Results}

The results of the questionnaire assessment analyzed using descriptive statistics showed that the implementation of the scientific method in learning physical education had gone very well. This is evidenced by the percentage value of the assessment of more than $75 \%$, both in the initial, core, and final activity variables (Table 1). Furthermore, statistical descriptive analysis was also carried out by classifying the assessment according to gender. In general, the average results of statistical descriptive analysis on male and female students showed that the percentage of assessments exceeded the standard, namely $75.85 \%$ for male students and $78.46 \%$ for female students (Table 2).

Table 1. The results of a descriptive statistical analysis based on the overall data

\begin{tabular}{ccccccccc}
\hline \multicolumn{8}{c}{ Descriptive Statistics } \\
\hline Variable & $\mathbf{N}$ & Min & Max & Sum & Mean & Std. Deviation & Variance & Percent (\%) \\
\hline Initial & & 13 & 52 & 4889 & 42.15 & 8.255 & 68.144 & 81.05 \\
Core & 116 & 15 & 60 & 5236 & 45.14 & 9.067 & 82.207 & 75.22 \\
Final & & 7 & 20 & 1754 & 15.12 & 2.993 & 8.959 & 75.60 \\
Average & 116 & 11.66 & 44 & 3959.66 & 34.13 & 6.77 & 53.10 & 77.29 \\
\hline
\end{tabular}

Table 2. The results of a descriptive statistical analysis based on gender

\begin{tabular}{ccccccc}
\hline \multicolumn{7}{c}{ Descriptive Statistics Based on Gender } \\
\hline Male & $\mathbf{N}$ & Min & Max & Mean & Std. Deviation & Percent (\%) \\
\hline Initial & & 13 & 52 & 41.12 & 9.461 & 79.06 \\
Core & 52 & 15 & 60 & 44.85 & 10.865 & 74.74 \\
Final & & 7 & 20 & 14.75 & 3.366 & 73.75 \\
Average & 52 & 11.66 & 44 & 33.57 & 7.89 & 75.85 \\
\hline Female & $\mathbf{N}$ & Min & Max & Mean & Std. Deviation & Percent (\%) \\
\hline Initial & & 19 & 52 & 42.98 & 7.095 & 82.66 \\
Core & 64 & 20 & 60 & 45.38 & 7.373 & 75.62 \\
Final & & 8 & 20 & 15.42 & 2.642 & 77.10 \\
Average & 64 & 15.66 & 44 & 34.59 & 5.70 & 78.46 \\
\hline
\end{tabular}

After getting the results of descriptive statistical analysis, the next step was to describe the results of interviews from physical education teachers. The results of teacher interviews were categorized and mapped into several relevant to the research objectives (Table 3). The results of this teacher interview were used as the supporting data to determine the protocol for implementing scientific methods in learning physical education. 
Table 3. Description of the results of the physical education teacher interview

\begin{tabular}{|c|c|c|}
\hline Theme & Sub-Theme & Description \\
\hline \multirow[t]{2}{*}{$\begin{array}{l}\text { Concept of } \\
\text { Physical } \\
\text { Education }\end{array}$} & $\begin{array}{l}\text { The Meaning of Physical } \\
\text { Education Learning }\end{array}$ & $\begin{array}{l}\text { Learning that emphasizes the development } \\
\text { of psychomotor, cognitive, affective, and } \\
\text { social aspects. }\end{array}$ \\
\hline & $\begin{array}{l}\text { The Uniqueness of } \\
\text { Physical Education } \\
\text { Learning }\end{array}$ & $\begin{array}{l}\text { Physical education learning has its own } \\
\text { uniqueness when compared to other } \\
\text { subjects, because it emphasizes the } \\
\text { achievement of educational goals through } \\
\text { movement, physical activity, and sports. }\end{array}$ \\
\hline \multirow{3}{*}{$\begin{array}{l}\text { The } 2013 \\
\text { Curriculum }\end{array}$} & Implementation of 2013 & Implementation of the 2013 curriculum at \\
\hline & Curriculum & $\begin{array}{l}\text { SMA Negeri } 3 \text { Mataram has been } \\
\text { implemented since } 2017 .\end{array}$ \\
\hline & $\begin{array}{l}\text { Problems in the } 2013 \\
\text { Curriculum }\end{array}$ & $\begin{array}{l}\text { The complexity of the process of preparing } \\
\text { learning and assessment tools. }\end{array}$ \\
\hline \multirow[t]{2}{*}{$\begin{array}{l}\text { The Scientific } \\
\text { Method }\end{array}$} & $\begin{array}{l}\text { Implementation of } \\
\text { Scientific Method }\end{array}$ & $\begin{array}{l}\text { It is still not optimally done because teachers } \\
\text { still need to be given understanding through } \\
\text { socialization related to scientific methods. }\end{array}$ \\
\hline & $\begin{array}{l}\text { Advantages and } \\
\text { Disadvantages of the } \\
\text { Scientific Method }\end{array}$ & $\begin{array}{l}\text { The advantage is that it can increase } \\
\text { students' interest in participating in } \\
\text { learning, especially material that is more } \\
\text { focused on recreational activities or games. } \\
\text { Meanwhile, the drawback is related to the } \\
\text { implementation procedures that are too } \\
\text { structured, such as; observing, questioning, } \\
\text { experimenting, associating, and forming } \\
\text { communication. }\end{array}$ \\
\hline
\end{tabular}

\section{Discussion}

Students Perception

Students' perceptions were obtained through a questionnaire sheet assessing the results of the implementation of scientific methods in physical education learning. The results of the student questionnaire analysis are divided into 2 stages, namely descriptive statistical analysis as a whole and gender-based. The results of the statistical descriptive analysis Table 1 show that the overall implementation of the scientific method in physical education learning has been as expected. This is evidenced by the percentage of assessments that exceed $75 \%$. The percentage standard of this assessment is in accordance with the proposal from Francis et al. (2016) which explains that consensus is typically defined as agreement among $75 \%$ of the participants.

The average result of statistical descriptive analysis as a whole shows a percentage value of $77.29 \%$, which means that the implementation of the scientific method in physical education learning has very good criteria. These results further strengthen several theoretical and empirical studies that show the effectiveness of the scientific method in learning physical education. Theoretically, the scientific method describes the general steps of what is the popular view of the scientific method and contributes to the redefinition of science as an everyday problem-solving activity (Rudolph, 2005). The scientific method can be a guide for teachers to encourage children to make observations, ask questions, predict, experiment, and discuss 
findings, so as to support the development of language, literacy, and mathematics (Gerde et al., 2013). Meanwhile, if it is associated with the context of physical education learning or empirical research results, the scientific method is able to have a positive impact on increasing students' motivation, movement skills, and academic abilities (Mustafa \& Winarno, 2020; Rasberry et al., 2011; Sebire et al., 2013; Ulstad et al., 2016).

Furthermore, if analyzed in more detail in Table 1, the percentage of values that have been divided based on the assessment variables, namely initial activities (81.05), core activities (75.22), and final activities (75.60). These three variables have a percentage value above $75 \%$ with very good criteria. This variable also represents an assessment of physical education learning activities using scientific methods from the initial to the final of learning. The initial activity emphasizes the search for information and responses from students related to activities carried out at the beginning of learning, such as; marching, praying, attending, apperception, explaining the objectives and learning materials, increasing motivation, and warming up. This initial activity is very familiar to do to start physical education learning in Indonesia (Pambudi et al., 2019). As such, it is not only considered as a mere formality but has become a positive habit or culture to instill social and spiritual attitudes in students (Nesdoly et al., 2020; Restiyanti et al., 2017; Winarni, 2011).

Furthermore, the core activities emphasize the implementation of scientific methods in physical education learning, such as; observing, questioning, experimenting, associating, and communicating. In core activities or during the learning process, students are given the opportunity to carry out scientific activities to stimulate students' cognitive, affective, and psychomotor abilities (Sun et al., 2017), or student-centered learning (D. Barker \& Annerstedt, 2016). For the final activity, learning has entered the final phase of activity which emphasizes the evaluation process related to the learning that has been carried out, the delivery of further learning materials, and muscle relaxation after doing physical activity or sports. This phase is also very important to do so that students better understand their involvement in the activities that have been carried out and continue to be motivated to carry out physical activities and sports (Stolz \& Pill, 2014).

Table 2 classifies by gender with an average percentage score of $75.85 \%$ for male and $78.46 \%$ for female. If interpreted literally, this value indicates a very good criterion in the implementation of the scientific method in physical education learning. However, it cannot be generalized to be the only assessment parameter. There must be a more specific analysis to compare the percentage value of each variable measured, both for male and female gender (Van Acker et al., 2010). In male gender, the percentage value of each variable includes; initial activity (79.06), core activity (74.74), final activity (73.75), while for female gender, the percentage value of each variable includes; initial activity (82.66), core activity (75.62), final activity (77.10). This value indicates that if analyzed by gender, female students have a better percentage of scores compared to male students. The results are supported by observational data conducted by researchers during the process of implementing scientific methods in physical education learning at SMA Negeri 3 Mataram. For example, during the analysis of the concept of exercise and measuring the components of physical fitness, female students were more active in questioning, experimenting, and communicating the material presented. Gender differences, characteristics, backgrounds, attitudes, 
and knowledge of students can determine the seriousness and amount of effort made (Greenockle et al., 1990; Pangrazi \& Beighle, 2016).

\section{Teacher's Perspectives}

The discussion in this section emphasizes the teacher's perspective on the implementation of scientific methods in physical education learning. This teacher's perspective is used as supporting data from the results of student perceptions that have been obtained through questionnaires. It showed the suitability and trustworthiness of research data, both obtained through questionnaires and interviews (Frels \& Onwuegbuzie, 2013). From the interview, it was found that 3 main themes were representative to support the research data (see Table 3): the concept of physical education, 2013 curriculum, and the scientific method.

The concept of physical education emphasizes the balance of soul, mind, and body which is realized through the experience of movement, physical activity, or sports to achieve educational goals (Stolz, 2013). Based on this concept, the meaning of physical education is constructed through various experiences of movement, physical activity or sports that are obtained through formal education or school. Based on the results of interviews with physical education teachers at SMA Negeri 3 Mataram, revealing the meaning of physical education as a learning process that emphasizes the development of psychomotor, cognitive, affective, and social aspects of students. This meaning is ideal with the aim of physical education as a medium in providing a planned, progressive, and inclusive learning experience in the early years, primary education, and secondary education to help improve psychomotor skills, cognitive understanding, social skills, and emotional (psychological), even the spiritual attitude needed to live a physically active life (UNESCO, 2015). Furthermore, physical education also has its own uniqueness when compared to other subjects, because it emphasizes the achievement of educational goals through movement, physical activity, and sports. The purpose of education referred to here is to develop the potential of students as a whole who have confidence, character, are healthy, knowledgeable, creative, innovative, independent, and responsible (Pangalila, 2020). The meaning and uniqueness of physical education is the strength in maintaining the existence of physical education as an important or substantive subject in schools (Irmansyah, Sakti, et al., 2020).

The 2013 curriculum has established physical education subjects as a medium in developing the character of students (Suherman, 2018). The 2013 curriculum policy aims to improve the various deficiencies contained in the previous curriculum, and is focused on developing and strengthening attitudes, knowledge, and skills in a balanced way (Machin, 2014). The achievement of goals and competencies in the 2013 curriculum is an important point in formulating models, methods, approaches, and learning strategies that are appropriate or according to the needs and characteristics of students. However, the results of interviews with physical education teachers showed contradictory results with the objectives of the 2013 curriculum formulation in Indonesia. In general, physical education teachers do not really understand all the components in the 2013 curriculum, such as; learning models, methods, strategies, approaches, and assessments. This is what makes physical education teachers consider the 2013 curriculum to have a higher complexity than the previous curriculum. The results of this interview are relevant to several previous studies which explain that in the implementation of the 2013 curriculum there are still many problems, such as; (a) differences in understanding of the 2013 curriculum caused by 
the gap in the quality of teachers from various regions; (b) teachers' knowledge of material coverage, competency descriptions, and learning resources is still limited; (c) lack of socialization, workshops, and training from the Education Office in accordance with the 2013 curriculum; (d) teachers' views on the implementation of the 2013 curriculum still do not meet the eligibility criteria; (e) inequalities of available learning infrastructure and facilities; (f) the supervisory function is not yet optimal; (g) learning assessment model that is too complicated; and (h) students are still not fully ready to take lessons in accordance with the 2013 curriculum (Adrina \& Suherman, 2018; Rosadi et al., 2019; Sigid \& Setiawan, 2018; Suherman, 2018; Sulistiyono et al., 2018; Susanto \& Sukoco, 2018).

The scientific method is one of the learning methods included in the 2013 curriculum. In the implementation of the scientific method, physical education teachers have carried out according to the procedures of the scientific method, such as; observing, questioning, experimenting, associating, and communicating. However, because this scientific method is a new method in learning physical education, there are still many shortcomings in its application. The results of observations in the field show that during the process of implementing the scientific method, the teacher only takes the aspects of questioning, experimenting, and communicating. The results of this observation are also corroborated by the results of teacher interviews which explain that scientific methods cannot be optimally implemented in physical education learning, and usually female students are more inclined and active in participating in learning. This point is in accordance with the results of the student responses above, which shows that the percentage of female students' scores is higher than that of male students. The ineffective implementation of the scientific method is due to the complexity of the method which emphasizes the process of seeking knowledge based on the scientific method (Vieira \& TenreiroVieira, 2016; Winnick \& Porretta, 2017). Also explains what science education should look like in the early twentieth century, where ideas about the position of the scientific method in education that will form the core of a new picture of the scientific process in schools. Theoretically, the scientific method has its own complexity in educational ideas, so that when implemented in the physical education learning process, it will definitely have an impact or incompatibility with the concept of physical education (Kirk, 2010).

\section{CONCLUSION}

The implementation of scientific methods in physical education learning has been carried out optimally by physical education teachers, and has resulted in positive responses from students. Students are more motivated in participating in the learning process which is indicated by the enthusiasm of students when asking questions, practicing the material, and communicating the difficulties they face. This is a fundamental transformation in the physical education learning process, because it has dared to make new breakthroughs by experimenting and implementing scientific methods, although there are still shortcomings during the physical education learning process, such as; (a) not all components in the scientific method can be implemented in physical education learning, (b) physical education teachers still do not fully understand the substance in the 2013 curriculum, (c) the complexity of the scientific method causes teachers to still need socialization from physical education academics 
as well as education policy makers, and (d) the need for the availability of standardized learning facilities to support the physical education learning process.

\section{RECOMMENDATION}

This study only describes the perceptions of students and teachers' perspectives regarding the implementation of scientific methods in physical education learning in class XI SMA Negeri 3 Mataram, so that there are still many limitations and obstacles faced in research. The limitations of this study are more emphasis on the research methodology used, because it only describes statistically the perceptions of students, while the physical education teacher interviews are also limited to knowledge related to the implementation of scientific methods. Future research is expected to conduct experiments related to the effectiveness of the scientific method in learning physical education at all levels of education. As such, it can envisage the efficacy of the scientific method at all levels of educations. Adaptation, modification, and innovation of various models, methods, approaches, strategies, and assessments of physical education learning at all levels of education must also be a priority in future research. This is done to support the development of science and improve the quality of physical education.

\section{ACKNOWLEDGMENT}

Thank you to the Lembaga Penelitian dan Pengabdian Masyarakat (LPPM) Universitas Pendidikan Mandalika (UNDIKMA) for supporting and funding this research through the 2021 Internal Higher Education Research Grant scheme, Number 16.a/L1/PP/UNDIKMA/2021.

\section{REFERENCES}

Adrina, B., \& Suherman, W. S. (2018). Identification of the obstacle factors for 2013 curriculum implementation of public junior high schools in Sleman district. Proceedings of the 2nd Yogyakarta International Seminar on Health, Physical Education, and Sport Science (YISHPESS 2018) and 1st Conference on Interdisciplinary Approach in Sports (CoIS 2018), 278, 153-155. https:// doi.org/10.2991/yishpess-cois-18.2018.40

Andayani, S., Hartati, S., Wardoyo, R., \& Mardapi, D. (2016). Combining rating scale and FANP to determine the important weight of learning competency for students' assessment. Advances of Science and Technology for Society: AIP Conference Proceedings, 1755, 070009. https:/ / doi.org/10.1063/1.4958504

Barker, D., \& Annerstedt, C. (2016). Managing physical education lessons: An interactional approach. Sport, Education and Society, 21(6), 924-944. https:// doi.org/10.1080/13573322.2014.969229

Barker, J., McCarthy, P., Jones, M., \& Moran, A. (2011). Single-case research methods in sport and exercise psychology. Routledge.

Bayu, W. I. (2018). Perubahan paradigma dalam pendidikan jasmani di sekolah. Prosiding Seminar Nasional Pendidikan Jasmani Dan Olahraga Program Studi Pendidikan Jasmani Dan Kesehatan STKIP PGRI Jombang, Jawa Timur, Indonesia, 28 Juli 2018, $1-6$. https:/ / ejournal.stkipjb.ac.id/index.php/prosiding/article/view/792/570

Beni, S., Fletcher, T., \& Ní Chróinín, D. (2017). Meaningful experiences in physical education and youth sport: A review of the literature. Quest, 69(3), 291-312. https:/ / doi.org/10.1080/00336297.2016.1224192 
Creswell, J. W., \& Poth, C. N. (2018). Qualitative inquiry and research design: Choosing among five approaches (4th ed.). SAGE Publications Inc.

Dole, S., Bloom, L., \& Kowalske, K. (2015). Transforming pedagogy: Changing perspectives from teacher-centered to learner-centered. Interdisciplinary Journal of Problem-Based Learning, 10(1), 1-15. https:/ / doi.org/10.7771/1541-5015.1538

Ennis, C. D. (2011). Physical education curriculum priorities: Evidence for education and skillfulness. Quest, 63(1), 5-18. https:// doi.org/10.1080/00336297.2011.10483659

Francis, C. E., Longmuir, P. E., Boyer, C., Andersen, L. B., Barnes, J. D., Boiarskaia, E., Cairney, J., Faigenbaum, A. D., Faulkner, G., Hands, B. P., Hay, J. A., Janssen, I., Katzmarzyk, P. T., Kemper, H. C. G., Knudson, D., Lloyd, M., McKenzie, T. L., Olds, T. S., Sacheck, J. M., ... Tremblay, M. S. (2016). The Canadian Assessment of Physical literacy: Development of a model of children's capacity for a healthy, active lifestyle through a Delphi process. Journal of Physical Activity and Health, 13(2), 214-222. https:/ / doi.org/10.1123/jpah.2014-0597

Frels, R. K., \& Onwuegbuzie, A. J. (2013). Administering quantitative instruments with qualitative interviews: A mixed research approach. Journal of Counseling and Development, 91(2), 184-194. https://doi.org/10.1002/j.15566676.2013.00085.x

Gerde, H. K., Schachter, R. E., \& Wasik, B. A. (2013). Using the scientific method to guide learning: An integrated approach to early childhood curriculum. Early Childhood Education Journal, 41(5), 315-323. https://doi.org/10.1007/s10643013-0579-4

Gray, S., MacIsaac, S., \& Harvey, W. J. (2018). A comparative study of Canadian and Scottish students' perspectives on health, the body and the physical education curriculum: The challenge of 'doing' critical. Curriculum Studies in Health and Physical Education, 9(1), 22-42. https:/ / doi.org/10.1080/18377122.2017.1418179

Greenockle, K. M., Lee, A. A., \& Lomax, R. (1990). The relationship between selected student characteristics and activity patterns in a required high school physical education class. Research Quarterly for Exercise and Sport, 61(1), 59-69. https:/ / doi.org/10.1080/02701367.1990.10607478

Harsuki. (2013). Olahraga, pendidikan jasmani, kesehatan, dan rekreasi: Sebuah perdebatan etimologis. In T. C. Mutohir, A. Maksum, \& M. Muhyi (Eds.), Ilmu Keolahragaan di Indonesia (1st ed., pp. 42-53). Graha Media.

Irmansyah, J., Lumintuarso, R., Sugiyanto, F., \& Sukoco, P. (2020). Children's social skills through traditional sport games in primary schools. Cakrawala Pendidikan, 39(1), 39-53. https:// doi.org/10.21831/cp.v39i1.28210

Irmansyah, J., Sakti, N. W. P., Syarifoeddin, E. W., Lubis, M. R., \& Mujriah. (2020). Physical education, sports, and health in elementary schools: Description of problems, urgency, and understanding of teacher perspectives. Jurnal Pendidikan Jasmani Indonesia, 16(2), 115-131. https:// doi.org/10.21831/jpji.v16i2.31083

Jatmika, H. M., Hariono, A., Purwanto, J., \& Setiawan, C. (2017). Analisis kebutuhan guru pendidikan jasmani, olahraga dan kesehatan pasca program guru pembelajar. Jurnal Pendidikan Jasmani Indonesia, 13(1), 1-11. https:// doi.org/10.21831/jpji.v13i1.21021

Jones, I. (2015). Research methods for sports studies (3rd ed.). Routledge.

Kemendikbud Republik Indonesia. (2018). Peraturan Menteri Pendidikan dan 
Kebudayaan Republik Indonesia Nomor 37, Tahun 2018, tentang Kompetensi Inti dan Kompetensi Dasar Pelajaran pada Kurikulum 2013 pada Pendidikan Dasar dan Menengah.

Kemendikbud Republik Indonesia. (2019). Rencana pelaksanaan pembelajaran yang inspiratif. Pusat Kurikulum dan Pembelajaran, Badan Penelitian dan Pengembangan, Kementerian Pendidikan dan Kebudayaan.

Kirk, D. (2010). Physical education futures. Routledge Taylor \& Francis Group.

Machin, A. (2014). Implementasi pendekatan saintifik, penanaman karakter dan konservasi pada pembelajaran materi pertumbuhan. Jurnal Pendidikan IPA Indonesia, 3(1),

28-36.

http://journal.unnes.ac.id/nju/index.php/jpii\%0ALITERASI

Memmert, D., Hillmann, W., Huttermann, S., Klein-Soetebier, T., Konig, S., Nopp, S., Rathschlag, M., Schul, K., Schwab, S., Thorpe, R., Furley, P., Almond, L., Bunker, D., Butler, J., Fasold, F., \& Griffin, L. (2015). Top 10 research questions related to teaching games for understanding. Research Quarterly for Exercise and Sport, 86(4), 347-359. https:/ / doi.org/10.1080/02701367.2015.1087294

Mustafa, P. S., \& Winarno, M. E. (2020). Penerapan pendekatan saintifik dalam aktivitas belajar pendidikan jasmani, olahraga, dan kesehatan di SMK Negeri 4 Malang. Jurnal Penjakora, 7(2), 78-92. https:/ / ejournal.undiksha.ac.id/index.php/PENJAKORA/article/view/2563 3

Nesdoly, A., Gleddie, D., \& McHugh, T.-L. F. (2020). An exploration of indigenous peoples' perspectives of physical literacy. Sport, Education and Society, 1-14. https:// doi.org/10.1080/13573322.2020.1731793

O'Donoghue, P. (2012). Statistics for sport and exercise studies: An introduction. Routledge.

Pambudi, M. I., Winarno, M., \& Dwiyogo, W. D. (2019). Perencanaan dan pelaksanaan pembelajaran pendidikan jasmani olahraga kesehatan. Jurnal Pendidikan Olahraga, Universitas Negeri Malang, 4(1), 110-116. http://journal.um.ac.id/index.php/jptpp/

Pangalila, T. (2020). Character education: The future key for developing Indonesian citizens with character. In K. J. Kennedy \& J. C.-K. Lee (Eds.), Religious Education in Asia: Spiritual Diversity in Globalized Times (1st ed., pp. 76-89). Routledge.

Pangrazi, R. P., \& Beighle, A. (2016). Dynamic physical education for elementary school children (18th ed.). Pearson Education, Inc.

Permatasari, N. H. I. (2017). Implementasi pembelajaran PJOK berdasarkan kurikulum 2013 di SMP Negeri se-Kecamatan Bantul tahun ajaran 2016/2017. Universitas Negeri Yogyakarta.

Rachman, H. A. (2011). Keterlaksanaan pendidikan jasmani dan olahraga di Daerah Istimewa Yogyakarta. Jurnal Pendidikan Jasmani Indonesia, 8(1), 38-47. https:/ / doi.org/10.21831/jpji.v8i1.3482

Rahmat, R., Suwardi, S., \& Suyudi, I. (2019). Implementasi pendekatan saintifik pada pembelajaran pendidikan jasmani olahraga dan kesehatan (PJOK) SD kurikulum 2013 di Kabupaten Bantaeng. SPORTIVE: Journal Of Physical Education, Sport and Recreation, 2(2), 63. https:// doi.org/10.26858/sportive.v2i2.9502

Rasberry, C. N., Lee, S. M., Robin, L., Laris, B. A., Russell, L. A., Coyle, K. K., \& Nihiser, A. J. (2011). The association between school-based physical activity, including 
physical education, and academic performance: A systematic review of the literature. Preventive Medicine, 52(SUPPL.), S10-S20. https:// doi.org/10.1016/j.ypmed.2011.01.027

Restiyanti, D., Sutarto, J., \& Suminar, T. (2017). Social skills's analysis of elementary students in strengthening implementation of character education. Journal of Primary Education, 6(3), 242-247. https:/ / doi.org/10.15294/JPE.V6I3.21138

Rosadi, D., Rahayu, T., \& Soenyoto, T. (2019). Problems with curriculum 2013 implementation in physical health education (PJOK) of junior high school in sub rayon 05 gunungjati district cirebon regency. Journal of Physical Education and Sports, 8(1), 62-68. https:// doi.org/10.15294 /jpes.v8i1.26845

Rudolph, J. L. (2005). Epistemology for the masses: The origins of "the scientific method" in American schools. History of Education Quarterly, 45(3), 341-376. https:// doi.org/10.1111/j.1748-5959.2005.tb00039.x

Sebire, S. J., Jago, R., Fox, K. R., Edwards, M. J., \& Thompson, J. L. (2013). Testing a self-determination theory model of children's physical activity motivation: A cross-sectional study. International Journal of Behavioral Nutrition and Physical Activity, 10(1), 111. https://doi.org/10.1186/1479-5868-10-111

Sigid, M., \& Setiawan, C. (2018). Phenomenological study of experience and meaning on K-13 implementation by elementary physical education teacher Purworejo regency. Proceedings of the 2nd Yogyakarta International Seminar on Health, Physical Education, and Sport Science (YISHPESS 2018) and 1st Conference on Interdisciplinary Approach in Sports (CoIS 2018), 278, 76-81. https:// doi.org/10.2991/yishpess-cois-18.2018.18

Sinulingga, A., \& Nugraha, T. (2013). Penerapan pendekatan ilmiah pada pelajaran pendidikan jasmani olahraga dan kesehatan dan dampaknya pada siswa SMA Negeri 15 Medan. Pegagogik Olahraga, 53(9), 1689-1699. https:// doi.org/10.22245/jpor.v3i2.8208

Stolz, S. A. (2013). Phenomenology and physical education. Educational Philosophy and Theory, 45(9), 949-962. https:/ / doi.org/10.1080/00131857.2013.785355

Stolz, S. A., \& Pill, S. (2014). Teaching games and sport for understanding: Exploring and reconsidering its relevance in physical education. European Physical Education Review, 20(1), 36-71. https:// doi.org/10.1177/1356336X13496001

Suherman, W. S. (2018). Nation character building through physical education: Lesson learnes from 2013 Indonesian national curriculum. Proceedings of the 2nd Yogyakarta International Seminar on Health, Physical Education, and Sport Science (YISHPESS 2018) and 1st Conference on Interdisciplinary Approach in Sports (CoIS 2018), 278, 133-136. https:// doi.org/10.2991/yishpess-cois-18.2018.34

Sulistiyono, Suherman, W. S., \& Kurnianto, D. (2018). Physical education sport and health national curiculum and elite sport development: Policy, synergy, or conflict? Proceedings of the 2nd Yogyakarta International Seminar on Health, Physical Education, and Sport Science (YISHPESS 2018) and 1st Conference on Interdisciplinary Approach in Sports (CoIS 2018), 278, 558-562. https:// doi.org/10.2991/yishpess-cois-18.2018.141

Sun, H., Li, W., \& Shen, B. (2017). Learning in physical education: A self-determination theory perspective. Journal of Teaching in Physical Education, 36(3), 277-291. https:/ / doi.org/10.1123/jtpe.2017-0067

Susanto, E., \& Sukoco, P. (2018). Perception of physical education teachers on the implementation and evaluation of curriculum 2013. Proceedings of the 2 nd 
Yogyakarta International Seminar on Health, Physical Education, and Sport Science (YISHPESS 2018) and 1st Conference on Interdisciplinary Approach in Sports (CoIS 2018), 278, 236-240. https:/ / doi.org/10.2991/yishpess-cois-18.2018.59

Ulstad, S. O., Halvari, H., Sørebø, Ø., \& Deci, E. L. (2016). Motivation, learning strategies, and performance in physical education at secondary school. Advances in Physical Education, 6(1), 27-41. https:/ / doi.org/10.4236/ape.2016.61004

UNESCO. (2015). Quality physical education (QPE): Guidelines for policy-maker. United Nations Educational, Scientific and Cultural Organization (UNESCO).

Van Acker, R., Carreiro da Costa, F., De Bourdeaudhuij, I., Cardon, G., \& Haerens, L. (2010). Sex equity and physical activity levels in coeducational physical education: Exploring the potential of modified game forms. Physical Education $\mathcal{E}$ Sport Pedagogy, 15(2), 159-173. https:/ / doi.org/10.1080/17408980902877609

Vieira, R. M., \& Tenreiro-Vieira, C. (2016). Fostering scientific literacy and critical thinking in elementary science education. International Journal of Science and Mathematics Education, 14(4), 659-680. https://doi.org/10.1007/s10763-0149605-2

Wainwright, N., Goodway, J., Whitehed, M., Williams, A., \& Kirk, D. (2016). The foundation phase in Wales - A play-based curriculum that supports the development of physical literacy. Education 3-13, 44(5), 513-524. https:// doi.org/10.1080/03004279.2016.1176360

Winarni, S. (2011). Pengembangan karakter dalam olahraga dan pendidikan jasmani. Jurnal Cakrawala Pendidikan, 2, 124-139. https:// doi.org/10.21831/cp.v0i2.1460

Winnick, J. P., \& Porretta, D. L. (2017). Adapted physical education and sport (6th ed.). Human Kinetics. 